\title{
The sulphur and oxygen isotopic composition of anhydrite from the Upper Pechora Basin (Russia): new data in the context of the evolution of the sulphur isotopic record of Permian evaporites
}

\author{
Anatoliy R. GALAMAY ${ }^{1}$, Fanwei MENG ${ }^{2}$, Krzysztof BUKOWSKI ${ }^{3, *}$, Pei $\mathrm{NI}^{4}$, \\ Svetlana N. SHANINA ${ }^{5}$ and Oleg O. IGNATOVICH ${ }^{6}$ \\ 1 National Academy of Sciences of Ukraine, Institute of Geology and Geochemistry of Combustible Minerals, Naukova, 3a, \\ 79060 Lviv, Ukraine \\ 2 Chinese Academy of Sciences, Nanjing Institute of Geology and Paleontology, State Key Laboratory of Paleobiology and \\ Stratigraphy, Nanjing 210008, China \\ 3 AGH University of Science and Technology, Faculty of Geology, Geophysics and Environment Protection, Al. A. \\ Mickiewicza 30, 30-059 Kraków, Poland \\ 4 Nanjing University, State Key Laboratory for Mineral Deposit Research, School of Earth Sciences and Engineering, \\ Nanjing 210093, China \\ 5 Institute of Geology of the Komi Science Center, Urals Branch of RAS, Pervomayskaya 54, 167610 Syktyvkar, Russia \\ 6 "MIREKO" State Company, Gromova 75, 167983 Syktyvkar, Russia
}

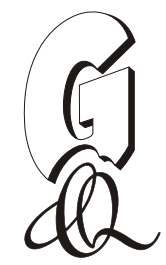

\begin{abstract}
Galamay, A.R., Meng, F., Bukowski, K., Ni, P., Shanina, S.N., Ignatovich, O.O., 2016. The sulphur and oxygen isotopic composition of anhydrite from the Upper Pechora Basin (Russia): new data in the context of the evolution of the sulphur isotopic record of Permian evaporites. Geological Quarterly, 60 (4): 990-999, doi: 10.7306/gq.1309

This study describes a new determination of the $S$ and $O$ isotope composition of Lower Permian (Kungurian) anhydrites from the Upper Pechora Basin, Cis-Ural region, Russia. $\delta^{34} S$ values in sulphate facies vary from +13.7 to $+15.1 \%$; and $\delta^{18} \mathrm{O}$ values range from +9.3 to $+10.4 \%$. The values of $\delta^{34} S$ and $\delta^{18} \mathrm{O}$ of anhydrite from halite facies varies from +12.6 to $+15.0 \%$ and +7.5 to $+10.9 \%$ respectively. The quantitative ratio of pyrite content from the water-insoluble residue (silty-sand fraction) is characterized by extremely low $(<<1 \%)$ to high $(4-5 \%)$ steep gradation values. The increased presence of pyrite indicates the influence of bacterial sulphate reduction. The sulphate reduction process was more intense, especially when evaporites were formed in mud. The narrow fluctuation range of sulphur and oxygen isotopes values of the measured anhydrite indicates low levels of fractionation. It was established that during the Permian, evolutionary changes in the content of sulphate ions in sea water correlate with the sulphur isotopic composition of marine evaporites.
\end{abstract}

Key words: Upper Pechora Basin, Permian, isotopic composition, anhydrite, pyrite, sulphate reduction.

\section{INTRODUCTION}

The sulphur and oxygen isotope composition in minerals is the tool that allows for the identification of the chemical, biochemical and physical processes that were occurring in the sedimentary basin. Variations of the sulphur isotopic composition of dissolved sulphates in ancient oceans have been established based on the analysis of ancient marine evaporites (e.g., Holser and Kaplan, 1966; Nielsen, 1972; Holser, 1979; Pankina, 1978; Claypool et al., 1980; Strauss, 1997). The main features of the sulphur isotope aged curve are a pronounced maxi-

* Corresponding author, e-mail: buk@agh.edu.pl

Received: May 15, 2016; accepted: July 19, 2016; first published online: September 5, 2016 mum with $\delta^{34} \mathrm{~S}$-values around $+30 \%$ o during Cambrian times, a decrease to a Permian minimum at $+10 \%$, and an increase towards the value for modern, oceanic sulphate at $+21 \%$ (Strauss, 1997 with references within). The observed variations are related to changes in ocean chemistry that are based, in principle, on variations of the sulphur redox cycle (Ronov, 1980; Yanshin, 1988; Kovalevich, 1990; Strauss, 1997; Holland, 2003). The sulphur isotopic content of the Permian evaporites has already been studied for many salt basins around the world (Table 1; Cortecci et al., 1981; Pankina et al., 1985; Makhnach et al., 2000; Vysotskiy et al., 2004; Longinelli and Flora, 2007; Shekhunova and Stadnichenko, 2010; García-Veigas et al., 2011). Detailed studies of the sulphur $\left(\delta^{34} S\right)$ isotopic composition of evaporites of Kungurian age were conducted mainly for the Caspian Basin (Makhnach et al., 2000); single data from the Upper Kama Basin (Solikamsk) have also been presented (Dzinoridze et al., 2000; Kovalevych et al., 2002).

The following study determines the sulphur $\left(\delta^{34} S\right)$ and oxygen $\left(\delta^{34} \mathrm{O}\right)$ isotope composition of the Lower Permian (Kun- 
The $\delta^{34} \mathrm{~S}$ and $\delta^{18} \mathrm{O}$ values of Permian marine evaporites (number of analyses given in parentheses)

\begin{tabular}{|c|c|c|c|c|c|}
\hline \multirow{2}{*}{ Age } & \multirow{2}{*}{ Basin location } & \multirow{2}{*}{ Facies } & \multicolumn{2}{|c|}{$\delta^{34} \mathrm{~S}, \%$} & \multirow{2}{*}{ References } \\
\hline & & & Range & Mean & \\
\hline \multirow{10}{*}{ Lopingian } & \multirow[t]{2}{*}{ Delaware, USA } & sulphate & $11.8-13.8$ & $12.2(6)$ & $\begin{array}{l}\text { Claypool et al. (1980); } \\
\text { Holser and Kaplan (1966) }\end{array}$ \\
\hline & & halite & $11.3-11.3$ & $11.3(4)$ & Claypool et al. (1980) \\
\hline & \multirow[b]{2}{*}{ Zechstein, Poland } & sulphate & $9.6-12.6$ & $11.4(52)$ & Peryt et al. (2010) \\
\hline & & halite & $8.84-13.29$ & $10.9(95)$ & $\begin{array}{l}\text { Kovalevych et al. (2002); Vovnyuk et al. (2004) } \\
\text { Peryt et al. (2005); García-Veigas et al. (2011) }\end{array}$ \\
\hline & \multirow{5}{*}{$\begin{array}{l}\text { Zechstein, } \\
\text { Peri-Baltic, Russia }\end{array}$} & sulphate & $12.41-12.88$ & $12.7(4)$ & Kovalevych et al. (2002); Vovnyuk et al. (2004) \\
\hline & & halite & $10.26-13.23$ & $11.9(13)$ & Kovalevych et al. (2002); Vovnyuk et al. (2004) \\
\hline & & $\begin{array}{l}\text { sulphate } \\
\text { (Strassfurt) }\end{array}$ & $10.1-11.8$ & $10.9(11)$ & $\begin{array}{l}\text { Nielsen and Ricke (1964); Holser and Kaplan (1966); } \\
\text { Kramm and Wedepohl (1991); Kampschulte et al. (1998) }\end{array}$ \\
\hline & & $\begin{array}{l}\text { sulphate } \\
\text { (Werra) }\end{array}$ & $10.5-12.6$ & $11.5(34)$ & $\begin{array}{c}\text { Nielsen and Ricke (1964); Claypool et al. (1980); Kramm } \\
\text { and Wedepohl (1991); Kampschulte et al. (1998) }\end{array}$ \\
\hline & & halite & $9.4-12.4$ & $10.7(15)$ & Holser and Kaplan (1966) \\
\hline & Denver, USA & $\begin{array}{l}\text { sulphate } \\
\text { (Satanka) }\end{array}$ & 12.6 & $12.6(1)$ & Holser and Kaplan (1966) \\
\hline & Average & values & & $11.6(235)$ & \\
\hline \multirow[b]{2}{*}{ Roadian } & \multirow{2}{*}{$\begin{array}{l}\text { Palo Duro, } \\
\text { western USA }\end{array}$} & sulphate & $10.5-16.8$ & $12.8(12)$ & Claypool et al. (1980); Makhnach et al. (2000) \\
\hline & & halite & $11.5-13.4$ & $12.6(8)$ & Claypool et al. (1980); Makhnach et al. (2000) \\
\hline \multicolumn{4}{|c|}{ Average values } & $12.7(20)$ & \\
\hline \multirow{4}{*}{ Kungurian } & \multirow{4}{*}{$\begin{array}{c}\text { Upper Pechora } \\
\text { Pricaspian, } \\
\text { Lower salt }\end{array}$} & sulphate & $13.7-15.1$ & $14.6(3)$ & our data \\
\hline & & halite & $12.6-15.0$ & $13.8(21)$ & our data \\
\hline & & sulphate & $11.0-16.4$ & $14.1(18)$ & Makhnach et al. (2000) \\
\hline & & halite & $10.5-15.1$ & $12.7(29)$ & Makhnach et al. (2000); Vovnyuk et al. (2004) \\
\hline \multicolumn{4}{|c|}{ Average values } & $13.8(71)$ & \\
\hline Artinskian & $\begin{array}{l}\text { Spitsbergen, } \\
\text { Norway }\end{array}$ & sulphate & $13.0-13.9$ & $13.2(4)$ & Claypool et al. (1980) \\
\hline \multirow{5}{*}{$\begin{array}{l}\text { Asselian- } \\
\text { Sakmarian }\end{array}$} & \multirow{2}{*}{$\begin{array}{l}\text { Dnipro-Donets, } \\
\text { Ukraine }\end{array}$} & sulphate & $13.1-13.2$ & $13.2(2)$ & Shekhunova and Stadnichenko (2010) \\
\hline & & halite & $8.4-11.6$ & $10.4(11)$ & Shekhunova and Stadnichenko (2010) \\
\hline & \multirow{2}{*}{$\begin{array}{l}\text { Dvina-Sukhona, } \\
\text { Belarus }\end{array}$} & sulphate & $13.12 \pm 0.07$ & $13.1(20)$ & Vysotskiy et al. (2004) \\
\hline & & halite & $11.77-13.76$ & $12.7(7)$ & Kovalevych et al. (2002) \\
\hline & Denver, USA & $\begin{array}{c}\text { sulphate, } \\
\text { (Wolfcampian) }\end{array}$ & $12.7-12.8$ & $12.8(2)$ & Holser and Kaplan (1966) \\
\hline \multicolumn{4}{|c|}{ Average values } & $12.4(42)$ & \\
\hline
\end{tabular}

gurian) anhydrite of the Upper Pechora Basin, Russia (Fig. 1). The aim of the research was to provide new data from the not previously investigated area and determine the potential impact of reduction processes on the isotopic composition of sulphates. In addition, in order to determine the intensity of bacterial sulphate reduction in a near-bottom depositional environment, the pyrite content was studied. Pyrite is regarded as a final product of the sulphate reduction process (e.g., Vinogradov, 1980 ) which is recorded indirectly by changes in the isotopic composition of anhydrites. The abundance and size of crystals of pyrite have been determined from the silty-sand fraction $(0.01-1 \mathrm{~mm})$ of the insoluble salt residue.

\section{GEOLOGICAL SETTING}

In Early Permian (Kungurian) times, evaporites (clastic-sulphate deposits, rock salts, and potash salts) were deposited in the Ural Foredeep. The largest basin - the Upper Kama salt ba- sin - located more to the south part of the Cis-Ural Depression (Fig. 1), occupies the Cherdyn-Solikamsk Depression where potash salt deposits were subsequently exploited (Solikamsk and Berezniki mines). The smaller basin, located to the north the Upper Pechora Sub-basin - is our study area. Both salt basins are separated by a transverse ridge that controlled water exchange (Ivanov and Voronova, 1972).

The Upper Pechora salt basin was discovered during gas-oil exploration in the 1950s and 1960s, when several widely separated salt deposits were found in the northern part of the Ural Foredeep (Cis-Ural Depression). The length of the Upper Pechora Basin is 125-130 km and the width is $50 \mathrm{~km}$ (Fig. 1); the area of the basin that has undergone evaporite sedimentation is approx. $6,000 \mathrm{~km}^{2}$.

The total thickness of the evaporite succession that accumulated in the Upper Pechora Basin ranges from 600-700 m (Strakhov, 1967). This evaporite sequence is part of the Lower Permian (Kungurian) succession known as the Irensk horizon or suite (e.g., Chuvashov, 1995) and includes three thick salt units: lower rock salt, potassium-magnesium salt, and upper 


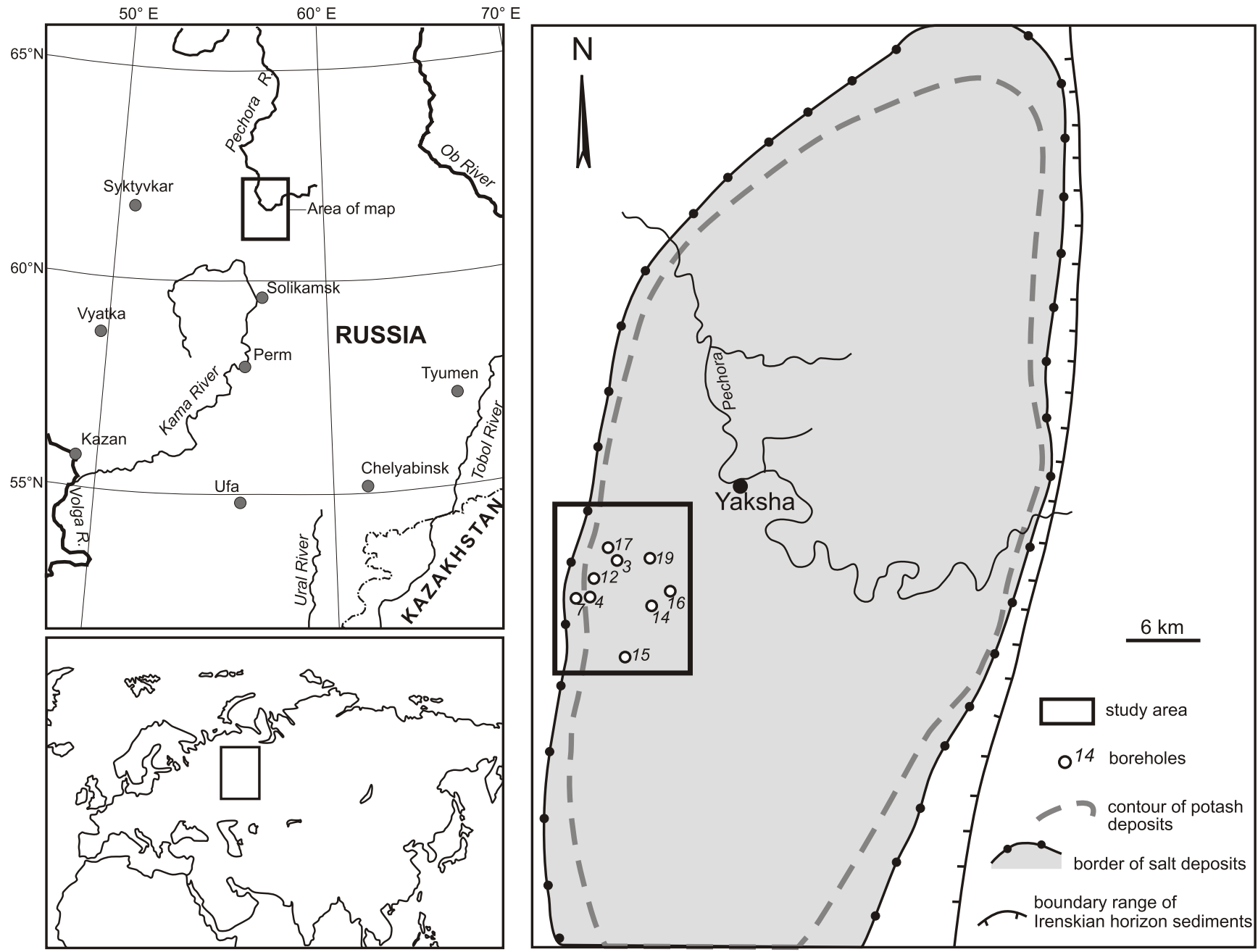

Fig. 1. Schematic map of the Upper Pechora salt-bearing basin

(after Foigt, 1965; Rayevskii et al., 1973; Vysotskiy et al., 1988; Shanina et al., 2012)

rock salt (Foigt, 1965; Ivanov and Voronova, 1968; Vysotskiy et al., 1988). The lower rock salt thickness varies from 125-130 m in the west to $400 \mathrm{~m}$ in the eastern part of basin. The potash salt horizon has a total thickness in the range of $8-63 \mathrm{~m}$. There are 4-7 beds of potassium-magnesium salt $(0.5-0.75 \mathrm{~m}$ each), mainly sylvite and carnallite. The maximum thickness of the upper rock salt is $80 \mathrm{~m}$ (Fig. 2). The characteristic feature of the salt formation in the Upper Pechora Basin is a high content of carbonate-terrigenous clay material in the form of layers and admixture, particularly in the initial stage of evaporitic deposition (Ivanov and Voronova, 1972). The evaporite formation is underlain by terrigenous deposits with limestones (Artinskian stage) and overlain by marly mudstones and sandstones (Ufimian) (Figs. 2 and 3).

The Kungurian saline formation in the Upper Pechora Basin as a whole is highly distinctive. First, the halite facies is extremely well-developed, in area and in total mass, among other deposits. At the same time, the distribution of deposit types shows a very clear asymmetry in the facies zone, both from east to west and from south to north (Fig. 1). This complex asymmetrical distribution of evaporites is associated with substrate tectonics. The dolomite-anhydrite, sulphate facies, formed on a relatively stable, only slightly-inclined floor to the centre of the basin and beds are therefore thinner. The halite facies developed over tectonically more mobile structures of the Ural Foredeep and the deposits are consequently much thicker (Strakhov, 1967). The potash salt accumulated in the most mobile and most intense subsidence zones (Fig. 3).

\section{MATERIALS AND METHODS}

For this study, the anhydrite from the sulphate facies was sampled from boreholes \#1 and 7, whilst anhydrites from the lower rock salt were sampled from boreholes \# 3, 12, 14, 16, 17 , 19. All these boreholes are located about $230 \mathrm{~km}$ north of Solikamsk (Fig. 1).

\section{PYRITE SAMPLE COLLECTION AND OBSERVATIONS}

Fragments of halite from lower rock salt formations were sampled (25-35 g each) from a borehole and were subsequently dissolved in distilled water. Previous studies of the insoluble fraction (Dzinoridze et al., 2000) showed that iron sulphide prevalence characterizes the pelitic fraction $(0.01 \mathrm{~mm})$ 


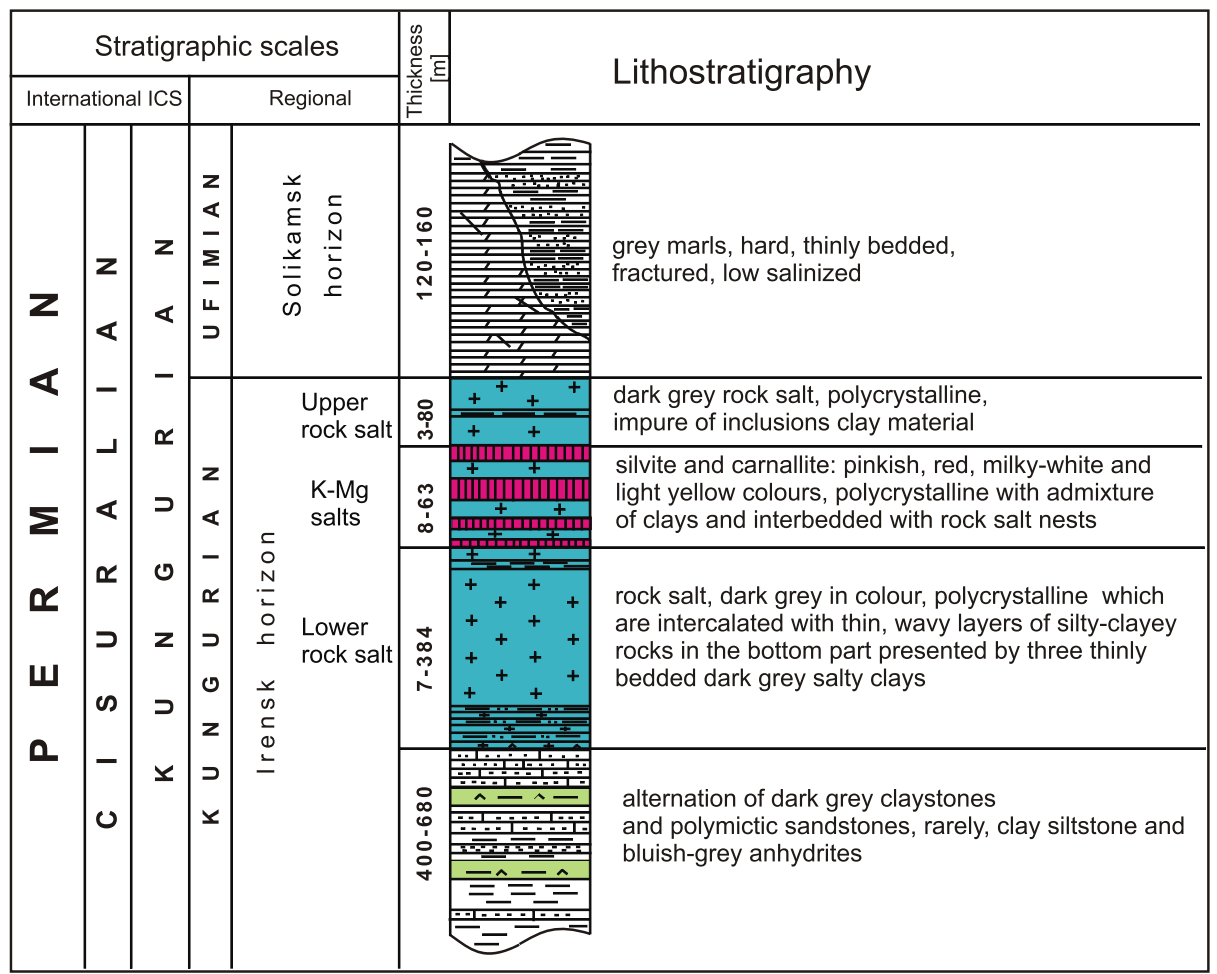

Fig. 2. Lithostratigraphic position of the Kungurian salts in the Upper Pechora Basin (after Foigt et al., 1965)

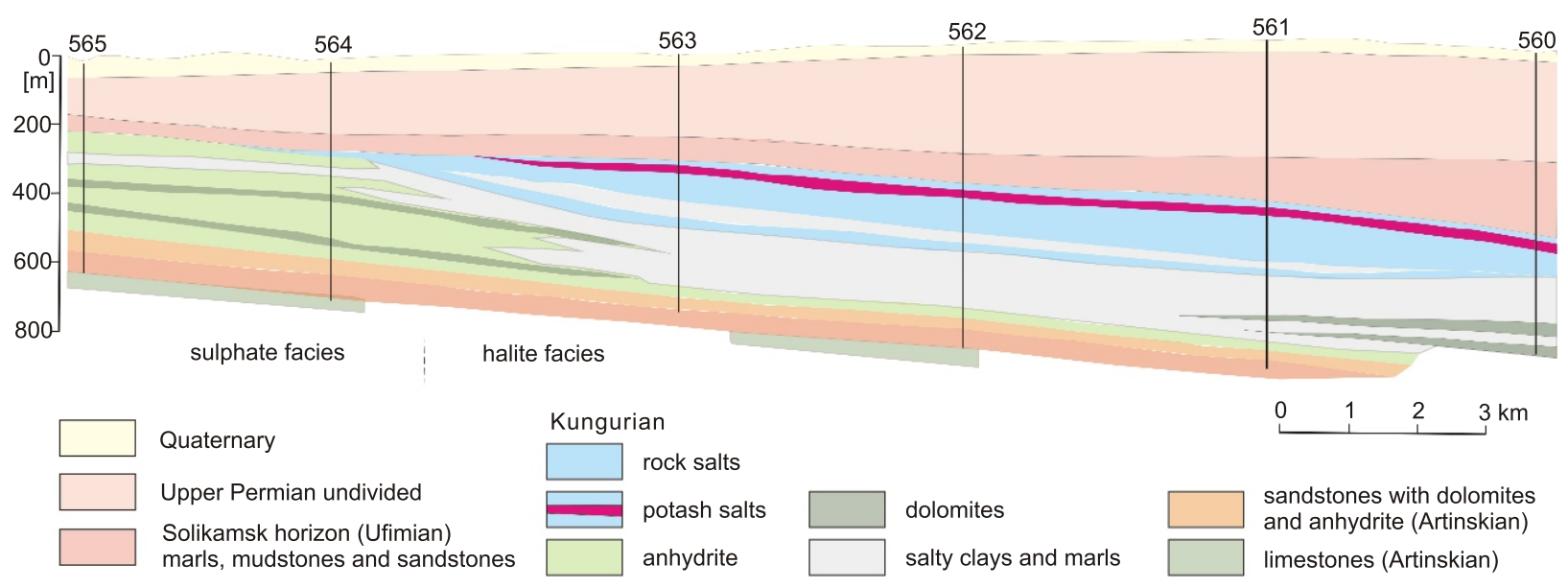

Fig. 3. Schematic geological cross-section of the Upper Pechora salt basin (after Ivanov and Voronova, 1968)

and larger size fraction (Fig. 4). In our study pyrite was particularly observed in the silty-sand fraction $(0.01$ to $1 \mathrm{~mm})$. Crystal microanalysis was completed using a SEM microscope (LEO $1530 \mathrm{VP}$ ) with X-Ray spectrometer following Laser Micro Spectrographic Methodology. Quantitative analysis of the pyrite content was completed by visual estimation of the crystals.

\section{ANHYDRITE SAMPLE COLLECTION AND ANALYTICAL PROCEDURE}

Massive anhydrite samples were collected from thick anhydrite beds, from cores of two boreholes located in the marginal part of the basin (sulphate facies), whilst nodular anhydrite was collected from crystals of halite, obtained after salt dissolution in distilled water. Nodular anhydrite occurs mainly among sedimentary layers and at the junctions of the individual halite crystals (Fig. 5).

Stable isotopic analyses $\left(\delta^{34} S\right.$ and $\left.\delta^{18} \mathrm{O}\right)$ of anhydrites were conducted by two laboratories: ALS (Australian Laboratory Services) Laboratory Group and Oxy-Anion Stable Isotope Consortium (OASIC) in Louisiana State University. The majority of isotopic analyses for the 21 samples were performed by ALS Laboratory Group; three analyses (samples 16/12, 3/19, 9/7) were performed by OASIC Laboratory.

The analytical workflows ALS laboratory used for sulphur isotopes are as follows: samples were weighted into tin cap- 

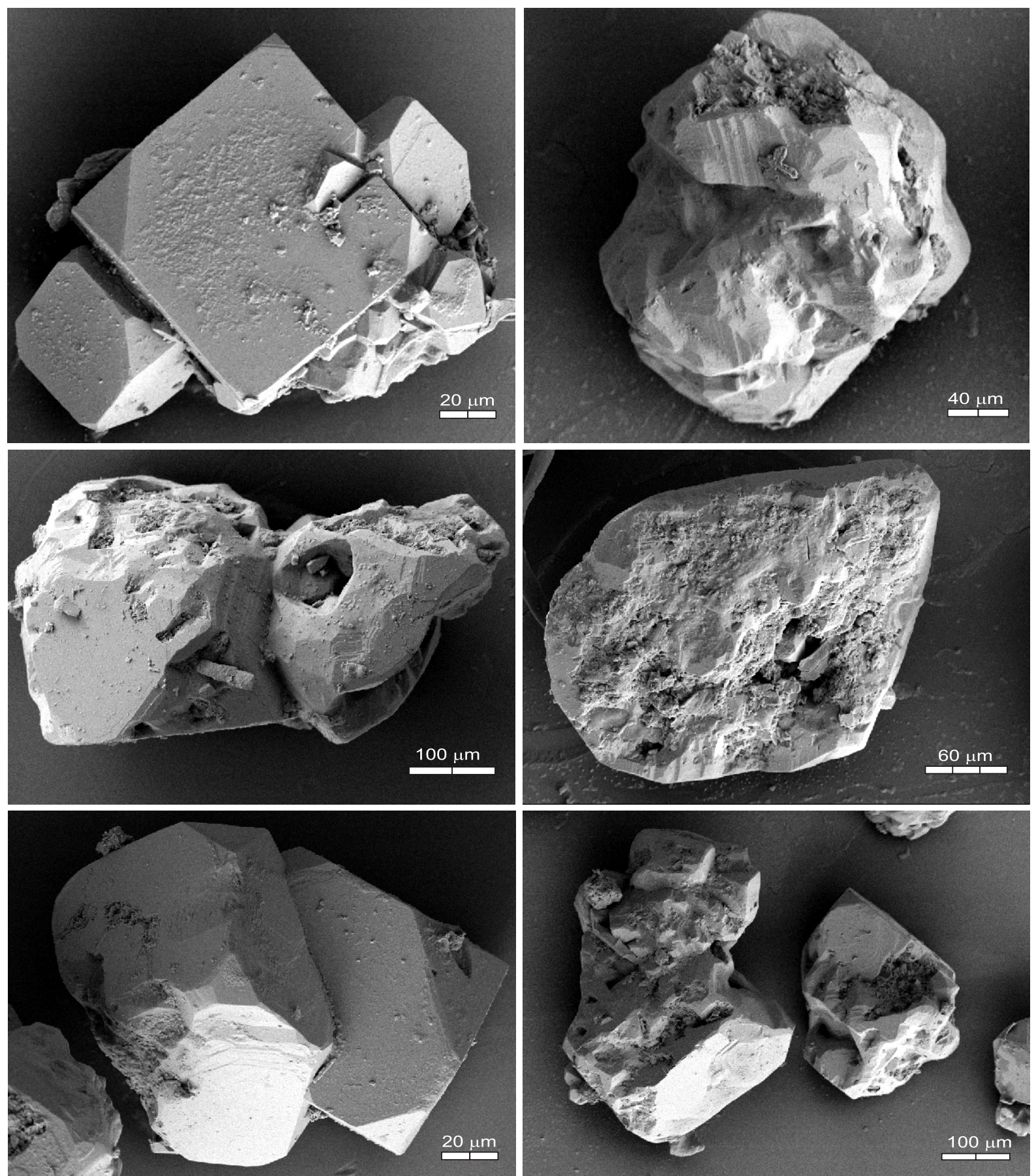

Fig. 4. Morphology of the pyrite grains, photo SEM microscope, borehole 16, sample 2/16

sules and the sulphur isotopic composition was measured using MAT 253 Stable Isotope Ratio Mass Spectrometer coupled to a Costech ECS 4010 Elemental Analyzer. Sulphur isotopic analyses were normalized to the VCDT standard.

Oxygen isotopes: samples were dissolved in $2 \mathrm{~N} \mathrm{HCl}$ and reprecipitated as $\mathrm{BaSO}_{4}$ by using a saturated solution of $\mathrm{BaCl}_{2}$. Precipitates were centrifuged, dried, and weighed into a silver capsule. The oxygen isotopic composition is measured using a MAT 253 Stable Isotope Ratio Mass Spectrometer coupled to a Thermo Scientific TC/EA High Temperature Conversion Elemental Analyzer. The $\delta^{18} \mathrm{O}$ values were calculated by normalizing the ${ }^{18} \mathrm{O} /{ }^{16} \mathrm{O}$ ratios in the sample to that in the Vienna Stan- dard Mean Ocean Water (VSMOW) international standard. All values were reported using the delta $(\delta)$ notation in units of permil $(\%)$ and reproducible to $0.2 \%$.

The analytical workflows used in the OASIC laboratory: the residual of acid treatment or extracted $\mathrm{BaSO}_{4}$ and $\mathrm{Ag}_{2} \mathrm{~S}$ precipitate were combined with excess $\mathrm{V}_{2} \mathrm{O}_{5}$ and analysed for concentration and isotope composition of sulphur using an Isoprime 100 (Isoprime 100, Cheadle, UK) gas source mass spectrometer fitted with a peripheral elemental analyser (Micro Vario Cube, Isoprime Ltd., Cheadle, UK) for on-line sample combustion. The analytical error is $<0.2 \%$, calculated from duplicate sample analyses and laboratory standards. 


\section{RESULTS}

\section{PYRITE OF THE ROCK SALT \\ SILTSTONE-SANDY FRACTION}

Pyrite occurs in numerous shapes and habits, for example as: isometric cubic crystals, octahedral, octahedral cubes, or aggregate concentrations with indistinct habits (Fig. 4). The ob- served yellow-brown single crystals have sizes not $<50 \mu \mathrm{m}$ and rarely $>200 \mu \mathrm{m}$. Mineral aggregates with pyrite crystals were observed as large as $500 \mu \mathrm{m}$, where besides pyrite, plagioclases (albite), K-feldspars, quartz, and single grains of wollastonite were found.

The abundance of pyrite in the samples was characterized by a strong contrast from low (<<1\%) to high (4-5\%) content of isolated crystals (Table 2).
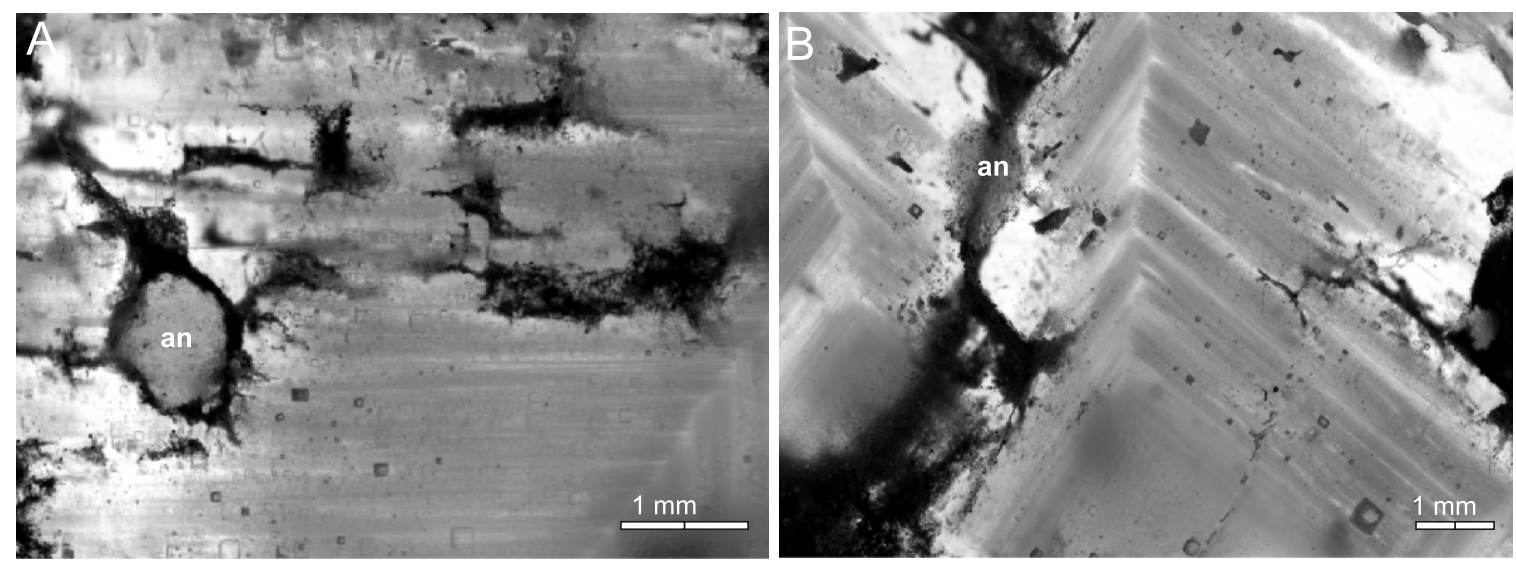

Fig. 5. Nodular anhydrite (an) within terrigenous material in chevron halite $(A)$ and at the junctions of the individual halite crystals (B), borehole 5 , sample $5 / 3$

Table 2

The $\delta^{34} \mathrm{~S}$ and $\delta^{18} \mathrm{O}$ values for anhydrite of the Upper Pechora Basin, thick anhydrite of sulphate facies, and insoluble residue of lower rock salt (halite facies)

\begin{tabular}{|c|c|c|c|c|c|c|}
\hline Borehole & Sample & $\begin{array}{c}\text { Interval } \\
{[\mathrm{m}]}\end{array}$ & $\begin{array}{l}\text { Content of pyrite within sandy-silt } \\
\text { fraction of the rock salt [\%] }\end{array}$ & $\begin{array}{c}\text { Sample } \\
\text { characteristics }\end{array}$ & $\begin{array}{l}\delta^{34} \mathrm{~S} \\
\% \circ \mathrm{CDT}\end{array}$ & $\begin{array}{c}\delta^{18} \mathrm{O} \\
\% \text { osmow }\end{array}$ \\
\hline \multirow{5}{*}{3} & $1 / 3$ & $420.6-420.7$ & 1 & \multirow{21}{*}{$\begin{array}{l}\text { nodular anhydrite } \\
\text { dispersed in halite, } \\
\text { lower rock salt }\end{array}$} & 13.8 & 8.9 \\
\hline & $2 / 3$ & $428.3-428.5$ & $2-3$ & & 14.8 & 9.8 \\
\hline & $4 / 3$ & $446.7-446.8$ & 1 & & 13.1 & 8.6 \\
\hline & $5 / 3$ & $450.25-450.35$ & 1 & & 13.3 & 8.7 \\
\hline & $6 / 3$ & $454.9-455.0$ & $<1$ & & 13.1 & 8.9 \\
\hline 12 & $16 / 12$ & $282.4-282.6$ & $2-3$ & & 15.0 & 10.9 \\
\hline \multirow{4}{*}{14} & $2 / 14$ & $429.5-430.1$ & $<1$ & & 13.4 & 8.1 \\
\hline & $3 / 14$ & $435.8-435.9$ & $2-3$ & & 14.1 & 9.1 \\
\hline & $6 / 14$ & $441.0-441.1$ & $2-3$ & & 13.8 & 9.5 \\
\hline & $8 / 14$ & $465.7-465.9$ & $1-2$ & & 14.2 & 10.0 \\
\hline \multirow{4}{*}{16} & $2 / 16$ & $468.4-468.5$ & $4-5$ & & 13.6 & 8.6 \\
\hline & $3 / 16$ & $474.3-474.4$ & $2-3$ & & 13.4 & 8.4 \\
\hline & $4 / 16$ & $481.4-481.6$ & $<1$ & & 12.6 & 8.6 \\
\hline & $5 / 16$ & $493.2-493.4$ & $1-2$ & & 14.6 & 9.4 \\
\hline \multirow{3}{*}{17} & $2 / 17$ & $373.7-373.9$ & $1-2$ & & 13.0 & 7.5 \\
\hline & $3 / 17$ & $377.6-377.7$ & $1-2$ & & 14.0 & 8.4 \\
\hline & $9 / 17$ & $409.1-409.2$ & 1 & & 13.9 & 8.7 \\
\hline \multirow{4}{*}{19} & $2 / 19$ & $454.5-454.7$ & $<1$ & & 13.5 & 7.8 \\
\hline & $3 / 19$ & 456.9 & $2-3$ & & 14.4 & 9.4 \\
\hline & $7 / 19$ & $483.6-483.7$ & $4-5$ & & 14.7 & 9.5 \\
\hline & $8 c / 19$ & $492.3-492.4$ & $<1$ & & 14.0 & 9.0 \\
\hline 15 & $22 / 15$ & $395.7-395.8$ & $\begin{array}{c}4-5 \\
\text { (pyrite and pyrrhotite) }\end{array}$ & $\begin{array}{c}\text { nodular anhydrite } \\
\text { dispersed in halite, } \\
\text { K-Mg salt }\end{array}$ & 13.2 & 8.7 \\
\hline 4 & $1 / 04$ & $220.85-222.35$ & - & $\begin{array}{l}\text { massive anhydrite } \\
\text { from the terrigenous } \\
\text { formation }\end{array}$ & 14.9 & 9.3 \\
\hline \multirow{2}{*}{7} & $10 / 7$ & $230.2-233$ & - & \multirow{2}{*}{$\begin{array}{l}\text { massive anhydrite } \\
\text { from the subsalt } \\
\text { anhydrite layer }\end{array}$} & 13.7 & 9.4 \\
\hline & $9 / 7$ & $230.1-230.2$ & - & & 15.1 & 10.4 \\
\hline
\end{tabular}




\section{THE SULPHUR AND OXYGEN ISOTOPIC COMPOSITION OF ANHYDRITE}

The oxygen and sulphur isotope analyses were determined on 24 anhydrite samples from the sulphate and halite facies. The measurement of the isotopic composition of sulphur for three samples of massive anhydrite from sulphate facies varies from +13.7 to $+15.1 \%$ (mean of $14.6 \pm 0.8 \%$ ); the isotopic composition of oxygen for the same samples varies from +9.3 to $+10.4 \%$ (mean of $9.7 \pm 0.6 \%$ ). The values of isotopic composition of sulphur and oxygen of anhydrite from halite facies (21 samples of nodular anhydrite) varies from +12.6 to $+15.0 \%$ o (mean of $13.8 \pm 0.6 \%$ ) and +7.5 to $+10.9 \%$ o (mean of $8.9 \pm$ $0.8 \%$ ) respectively. All results are presented in Table 2 . The mean $\delta^{34} \mathrm{~S}$ value for all samples analysed was $+13.9 \%$ with standard deviation of $\pm 0.7 \%$; the mean $\delta^{18} \mathrm{O}$ value for all samples was $+9 \%$ o with standard deviation of $\pm 0.8 \%$. The linear correlation coefficient for isotopic data of $\delta^{34} \mathrm{~S}$ and $\delta^{18} \mathrm{O}$ indicates quite a strong relationship: 0.77 in both facies (Figs. 7 and 8). The change of $\delta^{34} \mathrm{~S}$ and $\delta^{18} \mathrm{O}$ in the anhydrite halite facies is 2.4 and $3.4 \%$ (Fig. 6), whereas in the sulphate anhydrite facies the change is between 1.4 and $1.1 \%$.

\section{INTERPRETATION AND DISCUSSION}

The fluctuation in the observed isotope values of anhydrite can be explained by chemical and biological processes during sedimentation and early diagenesis in the evaporite basin (Pankina et al., 1985; Shekhunova and Stadnichenko, 2010; Galamay et al., 2014). Therefore, fractionation in $\delta^{34} S$ and $\delta^{18} O$ of dissolved sulphate occurs due to brine evaporation and crystallisation of gypsum (Thode and Monster, 1965; Holser and Kaplan, 1966; Nielsen, 1972; Pankina et al., 1985; Cendón et al., 2004). An important factor in the isotopic composition of
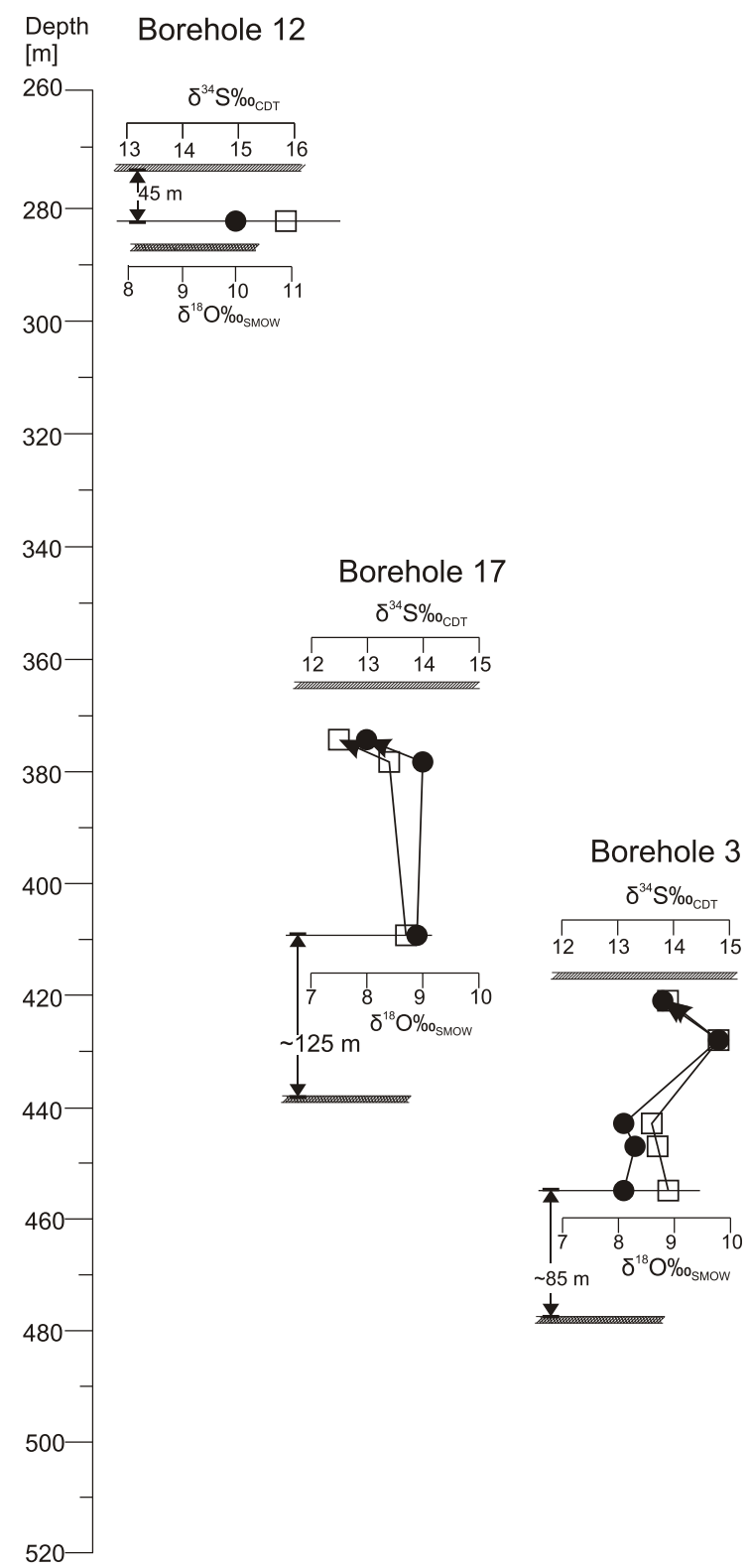

Fig. 6. The fluctuation values of $\delta^{34} S$ and $\delta^{18} \mathrm{O}$ of the anhydrite in borehole data of the Upper Pechora Basin

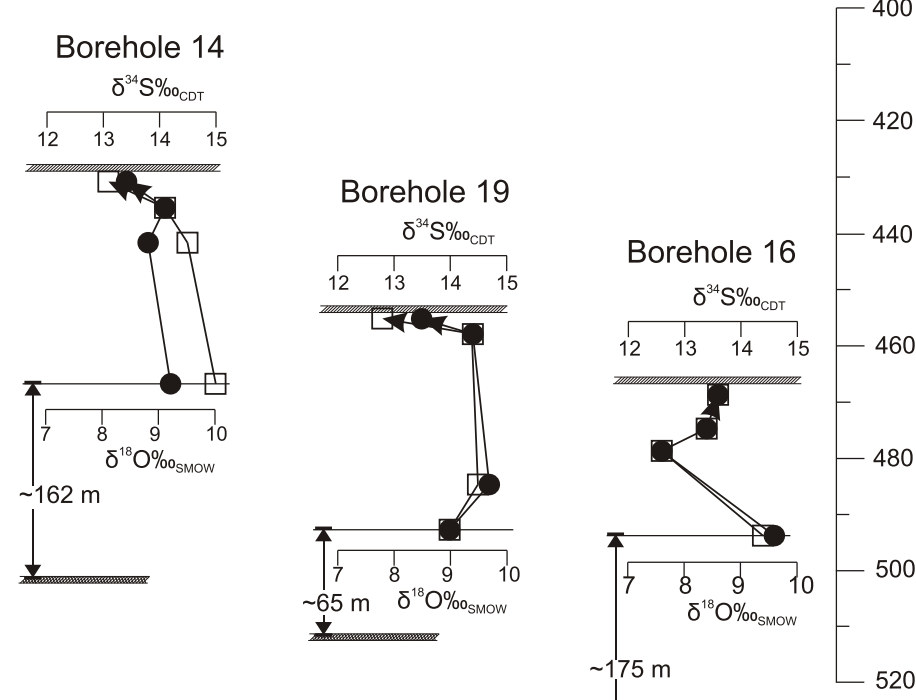




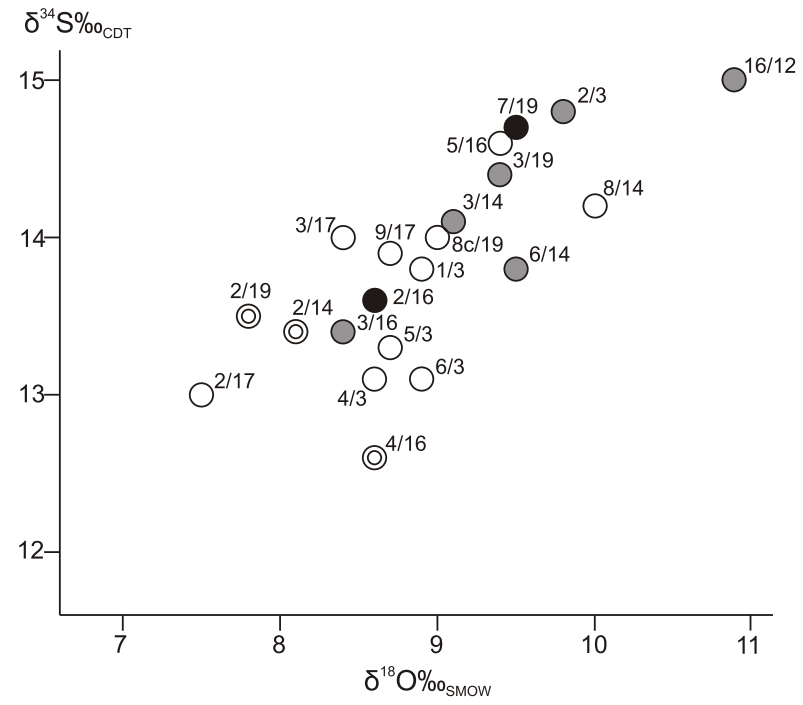

The content of pyrite in silty-sand fraction of rock salt

(a) $<1 \% 1 \% \quad \bigcirc-1 \% ; 1-2 \% \bigcirc 2-3 \% \bigcirc 4-5 \%$

Fig. 7. Correlation between sulphur and oxygen isotopic composition of nodular anhydrite (halite facies)

anhydrite is bacterial sulphate reduction (e.g., Vinogradov, 1980; Vysotskiy et al., 2004; Peryt et al., 2007), continental influx to a marine evaporite basin, and erosion of previously precipitated sulphates (e.g., Taberner et al., 2000).

Considering that evaporites of the Upper Pechora Basin have formed in a marine depositional environment (e.g., Strakhov, 1967; Galamay et al., 2013), the obtained $\delta^{34} S$ and $\delta^{18} \mathrm{O}$ results characterize the oxygen and sulphur isotopic composition of marine sulphates (gypsum and anhydrite) of Kungurian age. The presence of pyrite in insoluble rock salt residue of the Upper Pechora Basin (see Table 2) indicates bacterial sulphate reduction processes. Isotope fractionation during sulphate reduction by bacteria in organic-rich sediments leads to enrichment in the light stable isotope $\left({ }^{32} \mathrm{~S}\right)$ of hydrogen sulphide (as the earliest sulphate reduction product) and pyrite (as the final product of reduction). Vinogradov (1980) suggested that nearly all pyritic sulphur formed in the earliest periods of sediment diagenesis, and that the paragenesis of anhydrite and pyrite indicates a similar time of crystallisation for both minerals.

As shown in the diagram (Fig. 7), intensification of sulphate reduction (increase of pyrite content) does not in all cases lead to the enrichment of the heavy isotope $\left(\delta^{34} S\right)$ of anhydrite. This may indicate the simultaneous (synchronous) influence of other factors, such as crystal fractionation and the influx of continental waters. However, the sulphate reduction process was a determining factor of the fractionation of sulphur isotopes, especially when difficulties with intercrystalline replacement (in mud) with pre-bottom brine have contributed to this process. This hypothesis was supported in samples $2 / 3,16 / 12,8 / 14,5 / 16,3 / 19$, and $7 / 19$ by the presence of silty-sand fraction in dense lumps of clay and fine spongy anhydrite nodules, filled with clay, which has not been observed in other samples. The extensive development of bacterial sulphate reduction contributed to a high alkalinity of brine (Galamay et al., 2013) and a high content of organic matter buried in sediments. For example, the deficiency of such factors was the cause of the poor development of bacterial sulphate reduction in the Badenian saline basins (Peryt et al., 2002; Galamay et al., 2014).

As in the other formations, a clear decrease of the $\delta^{34} S$ value in anhydrite was observed in the upper part of lower rock salt unit, before deposition of potassium-magnesium salt in the Upper Pechora Basin (Table 2 and Fig. 6). This decrease of $\delta^{34} \mathrm{~S}$ value was in the range from 0.7 to $1 \%$, and $\delta^{18} \mathrm{O}$ in the range from 0.9 to $1.6 \%$. As shown by Raab and Spiro (1991), the $\delta^{34} S$ values of sequences resulting from evaporation in a closed basin decrease towards the end of the halite facies.

In previous studies (Holser and Kaplan, 1966; Claypool et al., 1980; Pankina et al., 1985), the $\delta^{34} S$ value of Permian anhydrite
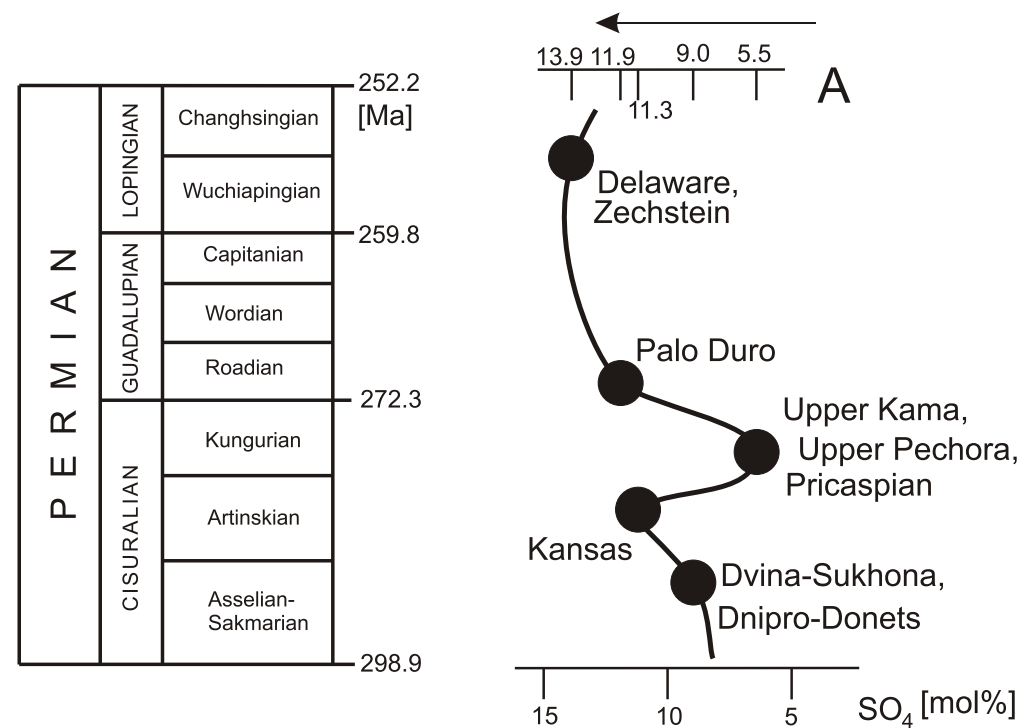

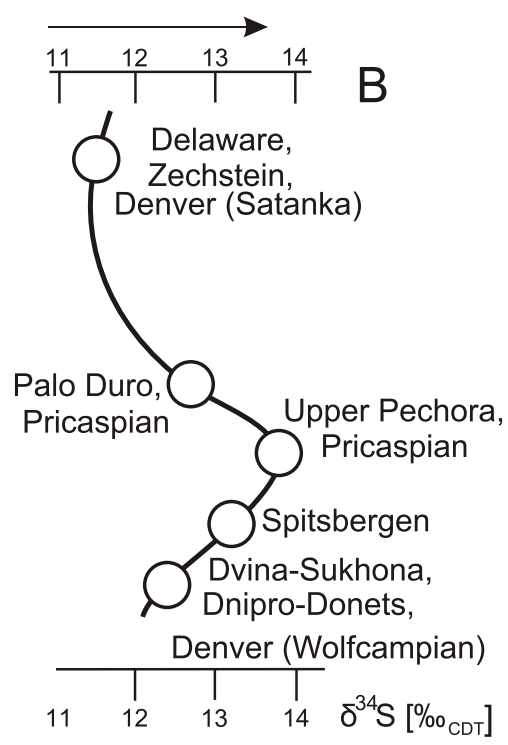

Fig. 8. Correlation between the concentration of sulphate ions in the brines of Permian salt basins and value $\delta^{34} \mathrm{~S}$ in anhydrites

A - the value curve of the sulphate ions content (Kovalevich and Vovnyuk, 2010); for calculating the content of sulphate ion, we used data from the following papers: Moskovskyi (1983), Petrychenko (1988), Horita et al. (1991), Kovalevych et al. (2002), Horita et al. (2002), Lowenstein et al. (2005), Galamay et al. (2013); B - the value $\delta^{34}$ S curve of anhydrites (according to Table 2) 
was established as an average value. Table 2 presents $\delta^{34} S$ and $\delta^{18} \mathrm{O}$ data of anhydrite characteristic for Permian marine evaporite deposits, which were formed with the minor influence of continental clastic input and isotope fractionation processes. The table data show that $\delta^{34} S$ of the anhydrite of Kungurian evaporites show a slightly different ${ }^{34} S$ concentration compared with the anhydrites of the Asselian-Artinskian and Ufa-Tatar basins. In contrast, sea water of the Kungurian interval has the lowest level of sulphate ions compared to other parts of the Permian. Therefore we suggest an inverse correlation between $\delta^{34} S$ anhydrite and the content of sulphate ions in brine from fluid inclusions of evaporite basins (Fig. 8). The trends of sulphur isotopic composition of sulphate anhydrite and halite facies are identical. It requires clarification of whether such a correlation is of a coincidental character or if the evolution of the isotopic composition of the dissolved marine sulphur was taking place during the entire Permian. Various researchers identified multidirectional (both direct and inverse) correlation between the content of sea water sulphate ions and sulphur evaporite isotopic composition, for the larger intervals (different periods) during Phanerozoic time (Kovalevych and Vityk, 1995; Algeo et al., 2015). It was induced by global change of the depositional ratio and erosion of sulphates or sulfides (Pankina, 1978; Nielsen, 1973; Claypool et al., 1980) and/or intensity of a biological sulphate reduction and other factors (Pankina, 1978).

\section{CONCLUSIONS}

New $\delta^{34} S$ and $\delta^{18} \mathrm{O}$ values for anhydrite from the Upper Pechora Basin are characteristic of marine evaporites of
Kungurian age and they differ slightly from Kungurian anhydrite from the Caspian Basin. The narrow fluctuation range of sulphur and oxygen isotope values of the measured anhydrite indicates their small fractionation. The fractionation was influenced by a variety of factors, mainly bacterial sulphate reduction processes. This is indicated by the presence of syngenetic pyrite (up to $5 \%$ ), in the water-insoluble residue (silty-sand fraction) from the halite. The Kungurian anhydrites are characterized by a higher $\delta^{34} S$ value compared to the anhydrites of the Asselian-Artinskian and Ufimian-Tatarian sequences.

Sulphates dissolved in sea water have varied through geologic time, which confirms the evolutionary changes in the Earth's history. A comparison with other Permian epochs shows that sea water of Kungurian age had the lowest content of sulphate ions calculated from the chemical composition of Xuid inclusions in halite. The results of the sulphur isotopic composition for all known Permian marine evaporites indicate that the highest values of $\delta^{34} S$ were recorded for evaporites of Kungurian age.

Acknowledgements. This research was supported by the National Natural Science Foundation of China (Nos: 41473039 and 4151101015) and the Bureau of International Co-operation, Chinese Academy of Sciences. Sulphur isotopic analyses were done at ALS (Australian Laboratory Services) Laboratory Group and at Louisiana State University by Dr. P. Yongbo. Microanalyses of pyrite were done at Nanjing Institute of Geology and Paleontology CAS by using SEM (LEO 1530 VP) with Energy-Dispersive X-Ray Spectrometer by engineer Fang Yan. We give our thanks to all of them for their help. Geological Quarterly reviewers Prof. A.A. Makhnach and Prof. J. Parafiniuk, and the editor Prof. T.M. Peryt are thanked for their helpful comments and suggestions.

\section{REFERENCES}

Algeo, T.J., Luo, G.M., Song, H.Y., Lyons, T.W., Canfield, D.E., 2015. Reconstruction of secular variation in seawater sulphate concentrations. Biogeosciences, 12: 2131-2151.

Chuvashov, B.I., 1995. Permian deposits of the Urals and Preduralye. In: The Permian of Northern Pangea, 2: Sedimentary Basins and Economic Resources (eds. P.A. Scholle, T.M. Peryt and D.S. Ulmer-Scholle): 158-183. Springer.

Claypool, G.E., Holser, W.T., Kaplan, I.R., Sakai, H., Zak, I., 1980. The age curves of sulphur and oxygen isotopes in marine sulphate and their mutual interpretation. Chemical Geology, 28: 199-260.

Cendón, C.I., Peryt, T.M., Ayora, C., Pueyo, J.J., Taberner, C., 2004. The importance of recycling processes in the Middle Miocene Badenian evaporite basin (Carpathian Foredeep): palaeoenvironmental implications. Palaeogeography, Palaeoclimatology, Palaeoecology, 212: 141-158.

Cortecci, G., Reyes, E., Berti, G., Casati, P., 1981. Sulphur and oxygen isotopes in Italian marine sulphates of Permian and Triassic ages. Chemical Geology, 34: 65-79.

Dzhinoridze, N.M., Aristarkhov, M.G., Polikarpov, A.I., Protopopov, A.L., Pavlensky, A.N., Plotnikov, A.U, Polyakovsky, V.Y., Aplonov, V.S., Drogomiretsky, D.I., Gemp, S.D., Mynka, U.V., Platygin, V.N., Khechoyan, K.S., 2000. The Petro-tectonic Basics of Safe Operation at the Verkhnekamsk Potassium-magnesium Salts Deposit (in Russian). St. Petersburg-Solikamsk, OGUP Solikamsk.

Foigt, V.P., Gladkov, I.P., Ivanov, P.I., Tarabrina, V.I., 1965. Report on the preliminary exploration of the Upper Pechora deposits of potash and rock salt (exploration and test drilling), Pechora (in Russian), 10. Funds Polar Urals Exploration Association.

Galamay, A.R., Savin, S.N., Ignatovich, O.O., 2013. Mineralizing composition of brine of the Upper Pechora halogenic basin at the stage of halite crystallization (in Russian). Notes of the RMO, 142: 32-46.

Galamay, A.R., Meng, F., Bukowski, K., 2014. Sulphur isotopes in anhydrite from Badenian (Middle Miocene) salts of the Hrynivka area (Ukrainian Carpathian Foredeep). Geological Quarterly, $\mathbf{5 8}$ (3): 429-438.

García-Veigas, J., Cendón, D.I., Pueyo, J.J., Peryt, T.M., 2011. Zechstein saline brines in Poland, evidence of overturned anoxic ocean during the Late Permian mass extinction event. Chemical Geology, 290: 189-201.

Holland, H.D., 2003. The geologic history of seawater. Treatise on Geochemistry, 6: 583-625.

Holser, W.T., 1979. Trace elements and isotopes in evaporites. Mineralogical Society of America Reviews in Mineralogy, 6: 295-346.

Holser, W., Kaplan, I., 1966. Isotope chemistry of sedimentary sulphates. Chemical Geology, 1: 92-135.

Horita, J., Friedman, T.J., Lazar, B., Holland, H.D., 1991. The composition of Permian seawater. Geochimica et Cosmochimica Acta, 55: 417-432.

Horita, J., Zimmermann, H., Holland, H.D., 2002. Chemical evolution of seawater during the Phanerozoic: implications from the record of marine evaporates. Geochimica et Cosmochimica Acta, 66: 3733-3756. 
Ivanov, A.A., Voronova, M.L., 1968. Geology of the Upper Pechora Saliferous Basin and its Potassium Potential (in Russian). Nedra, Leningrad.

Ivanov, A.A., Voronova, M.L., 1972. Halogenic Formations: Mineral Composition, Types, and Formation Environments (Methods of the Prospecting and Exploration of Mineral Salt Deposits) (in Russian). Nedra, Moscow.

Kampschulte, A., Buhl, D., Strauss, H., 1998. The sulphur and strontium isotopic compositions of Permian evaporites from the Zechstein basin, northern Germany. Geologische Rundschau, 87: $577-601$

Kovalevich, V.M., 1990. Halogenesis and Chemical Evolution of Ocean in the Phanerozoic (in Russian). Naukova Dumka, Kyiv.

Kovalevych, V.M., Vityk, M.O., 1995. Correlation of sulfur and oxygen isotopes in evaporites with chemical composition of brines of Phanerozoic evaporite basins (in Ukrainian). Dopovidi NAN Ukrainy, 3: 83-85.

Kovalevich, V.M., Vovnyuk, S.V., 2010. Secular variations in the chemical composition of the liquor and marine evaporite basins of the world ocean waters (in Russian). Geology and Mineral Resources of the Oceans, 4: 95-109.

Kovalevych, V.M., Peryt, T.M., Carmona, V., Sydor, D.V., Vovnyuk, S.V., Hałas, S., 2002. Evolution of Permian seawater: evidence from fluid inclusions in halite. Neues Jahrbuch für Mineralogie Abhandlungen, 178: 27-62.

Kramm, U., WedepohI, K.H., 1991. The isotopic composition of strontium and sulphur in seawater of Late Permian (Zechstein) age. Chemical Geology, 90: 253-262.

Longinelli, A., Flora, 0., 2007. Isotopic composition of gypsum samples of Permian and Triassic ages from the north-eastern Italian Alps. Palaeoenvironmental implications. Chemical Geology, 245: 275-284.

Lowenstein, T.K., Timofeeff, M.N., Kovalevych, V.M., Horita, J., 2005. The major ion composition of Permian seawater. Geochimica et Cosmochimica Acta, 69: 1701-1719.

Makhnach, A., Mikhajlov, N., Kolosov, I., Gulis, L., Shimanovich, V., Demeneva, O., 2000. Comparative analysis of sulphur isotope behavior in the basins with evaporites of chloride and sulphate types. Sedimentary Geology, 134: 343-360

Moskovskyi, G.A., 1983. Research of physical and chemical sedimentation conditions of the Kungurian salt sediments of the western part of the Caspian syncline based on inclusions in minerals (in Russian). Ph.D. thesis, Moscow.

Nielsen, H., 1972. Sulphur isotopes and the formation of evaporite deposits. Earth Sciences, 7: 91-102.

Nielsen, H., 1973. Model estimates of the balance of sulphur isotopes in ancient oceans of the Phanerozoic time. Internationa Geochemistry, Sedimentary Processes, 1: 127-140.

Nielsen, H., Ricke, W., 1964. Schwefelisotopen-Verhältnisse von Evaporiten aus Deuschland; ein Beitrag zur Kenntnis von $\delta^{34} S$ im Meerwasser-Sulfat. Geochimica et Cosmochimica Acta, 28 : 577-591.

Pankina, R.G., 1978. Geochemistry of Sulphur Isotopes, Oil and Organic Matter (in Russian). Nedra, Moscow.

Pankina, R.G., Mehdiyev, V.L., Guriev, S.M., 1985. Sulphur isotopic composition of modern and ancient evaporite formations halogen Caspian Depression (in Russian): 119-125. In: Lithofacial and Geochemical Problems of Salt Accumulation. Nauka, Moscow.

Peryt, T.M., Szaran, J., Jasionowski, M., Hałas, S., Peryt, D., Poberezhskyy, A., Karoli, S., Wójtowicz, A., 2002. S and O iso- topic composition of the Middle Miocene Badenian sulphates in the Carpathian Foredeep. Geologica Carpathica, 53: 391-398.

Peryt, T.M., Tomassi-Morawiec, H., Czapowski, G., Hryniv, S.P., Pueyo, J.J., Eastoe, C.J., Vovnyuk, S., 2005. Polyhalite occurrence in the Werra (Zechstein, Upper Permian) Peribaltic Basin of Poland and Russia: evaporite facies constraints. Carbonates and Evaporites, 20: 182-194.

Peryt, T.M., Makhnach, A.A., Hałas, S., Petrychenko, O.I., Gulis L.F., Abravets, S.M., 2007. Sulphur isotopes in anhydrites from the Upper Devonian Prypiac' and Dnipro-Donets Basins (Belarus and Ukraine). Carbonates and Evaporites, 22: 43-54.

Peryt, T.M., Hałas, S., Hryniv, S.P., 2010. Sulphur and oxygen isotope signatures of the late Permian Zechstein anhydrites, West Poland: seawater evolution and diagenetic constraints. Geological Quarterly, 54 (4): 387-400.

Petrychenko, O.I., 1988. Physico-chemical conditions in the sedimentation of the ancient halogen basins (in Russian). Naukova Dumka, Kyiv.

Raab, M., Spiro, B., 1991. Sulfur isotopic variations during seawater evaporation with fractional crystallization. Chemical Geology, 86: 323-333.

Rayevskii, V.I., Fiveg, M.P., Gerasimova, V.V., 1973. Deposits of Potassium Salts in the USSR; Methods of Exploration and Surveying (in Russian). Nedra, Leningrad.

Ronov, A.B., 1980. The Sedimentary Cover of the Earth (in Russian). Nauka, Moscow.

Shanina, S.N., Valyaeva, O.V., Ignatovich, O.O., 2012. Bitumens of underlying rock salts of Upper Pechora salt deposit (in Russian). Institute of Geology Komi UB RAS, Vestnik, 214: 22-25.

Shekhunova, S.B., Stadnichenko, S.N., 2010. Features of sulphur isotopic composition of the Lower Permian saline formation of the Dnieper-Donets Basin (in Ukrainian). Zbirnik Naukove Pratse Institutu Geokhimiï Navkolishnogo Seredovishcha, 18: 159-172.

Strakhov, N.M., 1967. Principles of Lithogenesis. Springer.

Strauss, H., 1997. The isotopic composition of sedimentary sulphur through time. Palaeogeography, Palaeoclimatology, Palaeoecology, 132: 97-118.

Taberner, C., Cendón, D.I., Pueyo, J.J., Ayora, C., 2000. The use of environmental markers to distinguish marine vs. continental deposition and to quantify the significance of recycling in evaporite basins. Sedimentary Geology, 137: 213-240.

Thode, H.G., Monster, R.J., 1965. Sulphur isotope geochemistry of petroleum, evaporites and ancient seas. AAPG Memoir, 4: 367-377.

Vinogradov, A.P., 1980. The Role of the Sedimentary Cycle in Geochemistry of Sulphur Isotopes (in Russian). Nauka, Moscow.

Vovnyuk, S., Kovalevych, V., Czapowski, G., Sydor, D., 2004. Geochemical peculiarities of formation of Upper Permian salts in eastern part of the Central European Basin (in Ukrainian with English summary). Geology and Geochemistry of Combustible Minerals, (2): 119-136.

Vysotskiy, E.A., Garetsky, R.G., Kislik, V.Z., 1988. Potash-bearing Basins of the World (in Russian). Institute of Electronics, Academy of Sciences of the Byelorussian SSR, Minsk.

Vysotskiy, E.A., Makhnach, A.A., Peryt, T.M., Kruchek, S.M., 2004. Marine and continental Lower Permian evaporites of the Prypiac' Trough (Belarus). Sedimentary Geology, 172: 211-222.

Yanshin, A.L., 1988. Evolution of Geological Processes in the Earth's History (in Russian). Nauka, Leningrad. 